Egyptian Journal of Aquatic Biology \& Fisheries

Zoology Department, Faculty of Science,

Ain Shams University, Cairo, Egypt.

ISSN $1110-6131$

Vol. 24(7): $441-452$ (2020)

www.ejabf.journals.ekb.eg

\title{
An evaluation for the exploitation level of Egyptian Marine Fisheries
}

\section{Shimaa I. Maiyza ${ }^{1 *}$; Sahar F. Mehanna ${ }^{2}$ Ibrahim A. El-karyoney ${ }^{3}$}

1.National Institute of Oceanography \& Fisheries (NIOF), Red Sea branch, Egypt.

2. National Institute of Oceanography \& Fisheries (NIOF), Suez and Aqaba Gulfs branch, Egypt.

3. National Institute of Oceanography and Fisheries (NIOF), Alexandria branch, Egypt.

"Corresponding Author: shemo iam@yahoo.com

\section{ARTICLE INFO}

Article History:

Received: April 26, 2020

Accepted: Nov. 1, 2020

Online: Nov. 3, 2020

Keywords:

Fish Stock assessment,

Surplus Production

Models,

Overfishing,

Egyptian marine fisheries,

Maximum Sustainable

Yield.

\section{ABSTRACT}

Egyptian marine fisheries contribute to the economy of the country where it provides an important source for food and employment. There are many challenges that affected the sustainability of marine fish stocks from which overfishing due to the increasing fishing effort. In the present study, annual catch and effort data were analyzed to estimate the maximum sustainable yield (MSY) and the corresponding level of fishing effort $\left(f_{\max }\right)$ for both the Mediterranean \& Red seas, Egypt. According to the Schaefer model (1954), the value of MSY was estimated at $73.0 * 10^{3}$ tons for Mediterranean sea fisheries, and at $63.1 * 10^{3}$ tons for Red sea fisheries. These values of MSY were obtained at fishing effort $\left(f_{\max }\right)$ of $3.5^{*} 10^{3} \&$ $1.6^{*} 10^{3}$ standard boats in Mediterranean \& Red seas respectively. The results indicated that the optimum exploitation in Egyptian marine fisheries required an urgent reduction in fishing effort. These results confirmed the overexploitation situation of the marine fish stocks in Egypt.

\section{INTRODUCTION}

The marine fishery resource provides important source for food and has been traditionally exploited for centuries in Egypt. With the rapid increase in the human population over the years, the demand for fish has increased considerably. During the last years there has been a growing awareness among the users about the need to conserve and manage marine fisheries resources based on data collected in a scientific manner so as to ensure proper utilization and maximum sustainable yield (MSY). Egypt has a long coastline on both Mediterranea $(1100 \mathrm{Km})$ and Red seas $(1080 \mathrm{Km})$. Egyptian marine fisheries (Fig. 1) has a rich and diverse commercial species varied from demersals, semipelagics, benthopelagics and pelagics. Over exploitation on the Egyptian coastal resources has caused decline of many fish, mollusc and crustacean stocks. Stock assessment of fishery is important for its effective management and the effective management strategy which based on a sound scientific basis can help to obtain sustainable yield every year (Mehanna and El-Gammal, 2007; Osman, 2015; El-Mahdy, 2017; Ali, 2017; Hassanein, 2017; Mehanna, 2020; Mohamed et al., 2020). The state of a 
fishery can be assessed by many mathematical models. Catch and effort statistics constitute the minimum requirements for the assessment of a fishery. Effort and catch per-unit effort statistics provide indices that are related to important quantities, such as the fishing mortality and the density of the exploited stock (Gulland, 1983). Surplus production models (SPMs) also known as biomass dynamics models (BDMs) are frequently used to evaluate MSY and to study the harvested population. These models need catch and effort data which is valued when age structured data are absent (Haddon, 2011). Surplus production models are used to determine the optimum level of effort which produces the maximum yield that can be sustained without affecting the long-term productivity of the stock, the so-called maximum sustainable yield (MSY). A number of studies were undertaken to estimate MSY of the marine fishery resources in Egypt based on SPMs (Mehanna, 2002, 2005, 2009; Mehanna and El-Gammal, 2007; Mehanna and Haggag, 2010; Mehanna et al., 2020).

The present study analysed the catch and effort data of Mediterranean and Red seas fish stocks to estimate the maximum sustainable yield (MSY) and the corresponding level of fishing effort $\left(f_{\max }\right)$ using Schaefer model (1954). The results of Schaefer (1954) model provide baseline information on maximum sustainable yield for the Egyptian marine waters, which could be useful for any future fishery assessment.

\section{MATERIALS AND METHODS}

A time series of catch and effort data for the period from 1995 to 2016 (22 years) were collected from two sources; the Central Agency of Public Mobilization and Fisheries Statistics (CAPMS) and General Authority for Fish Resources Development (GAFRD). Fishing effort is expressed by the number of operational fishing boats in the Egyptian marine waters of both Mediterranean and Red Sea. As the Egyptian marine fisheries is of multi-fleet nature, the fishing boats of different characteristics were standardized.

The surplus production model of Schaefer (1954) was applied in this study to the per annum total catch in tons and standardized number of fishing units. This model considered the stock as one big unit of biomass.

Schaefer model (1954) is one of Surplus production models, which can be used to estimate the maximum sustainable yield (MSY) and the corresponding level of fishing effort $\left(f_{\max }\right)$, expresses the catch per unit effort (CPUE) as a function of effort as follows:

Where: Y: yield (catch in weight),

$$
\mathbf{Y} / \mathbf{f}=\mathbf{a}+\mathbf{b} \mathbf{f}
$$

f: effort,

and Y/f: yield (weighted catch) per unit of effort.

By fitting the effort against catch per unit effort via ordinary least square method (OLS), the obtained parameters $a$ and $b$ can used to estimate the MSY and $f_{\mathrm{MSY}}$ using the following formulae:

$$
\begin{aligned}
M S Y & =-a^{2} / 4 b \\
f_{\text {msy }} & =-a / 2 b
\end{aligned}
$$


The slope (b) will be negative if the catch per unit effort (Y/f) decrease with the increase of effort (f) and vise versa.

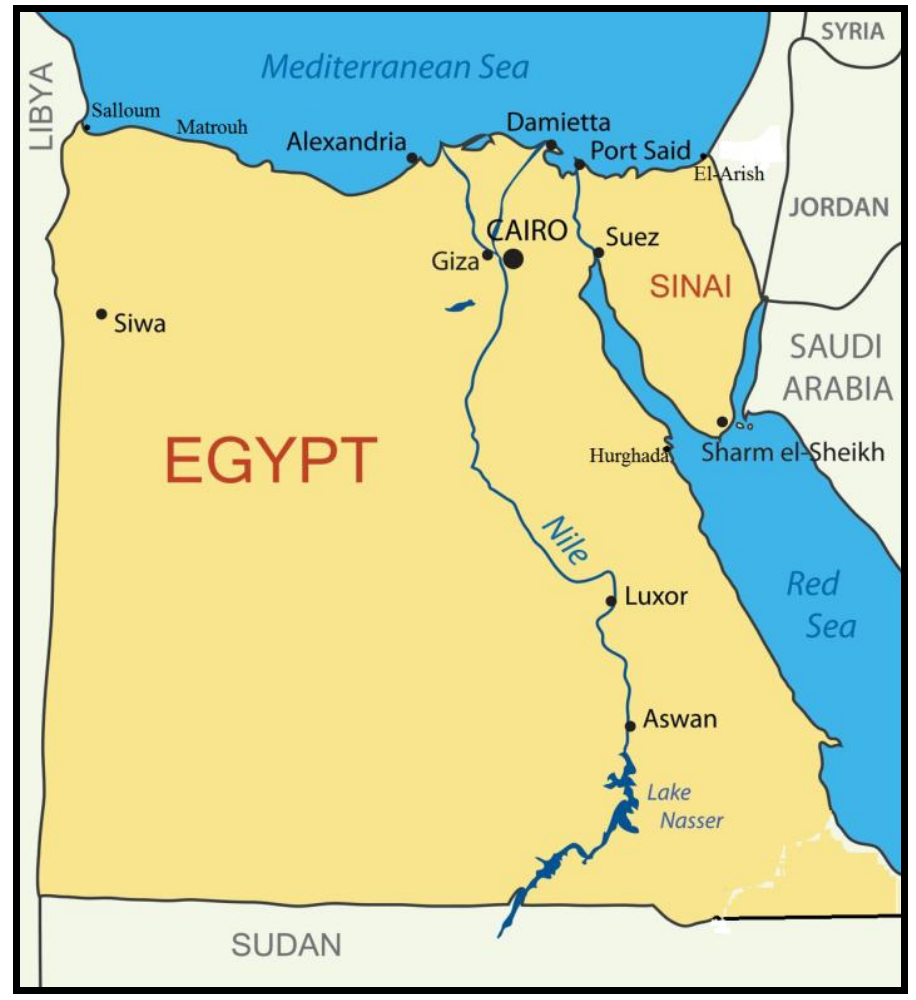

Fig.1. Egyptian Marine fisheries (Mediterranean and Red Seas coasts)

\section{RESULTS AND DISCUSSION}

\section{Egyptian marine fisheries}

Egypt drives its fish production from two resources; natural resources (marine and inland waters), and artificial resources or aquaculture. Egyptian Marine fisheries include two seas, Mediterranean sea in the north and Red sea in east of Egypt (Figs. 1\&2).

Egyptian Marine fisheries one of the most important sources for fish production in Egypt, and represented the largest area compared to other fish resources. The actual area of these fisheries are approximately about $11.2 * 10^{6}$ acre during the period of study (1995-2016), which represented about $84.8 \%$ of natural fisheries area and $80.5 \%$ of Egyptian fisheries area. While exploitable area of these fisheries is only about $31.8 \%$, $30.2 \%$ from natural fisheries area and Egyptian fisheries area consequently (Table 1).

The Mediterranean Sea fisheries area varies between actual and exploitable areas which are about $6.8^{*} 10^{6}$ and $3.3^{*} 10^{6}$ acre, whereas the Red Sea fisheries these areas are $4.4^{*} 10^{6}$ acre and $0.9^{*} 10^{6}$ acre for actual and exploitable areas respectively. As the area of Mediterranean Sea fisheries is greater than that of Red Sea fisheries, its contribution to the Egyptian natural fisheries is higher (Fig. 2). On the other hand, the coast length of Egyptian Marine fisheries is approximately about $2.4 * 10^{3} \mathrm{Km}$, divided to about $1.1 * 10^{3}$ 
$\mathrm{Km}(46 \%)$ for Mediterranean Sea fisheries and up to $1.3 * 10^{3} \mathrm{Km}(54 \%)$ for Red sea fisheries with its two Gulfs (Table 1).

Table 1. Relative actual and exploitable area of Egyptian marine fisheries during 19952016.

\begin{tabular}{|c|c|c|c|c|c|c|c|c|}
\hline \multirow{3}{*}{ Items } & \multicolumn{6}{|c|}{ Egyptian Marine fisheries } & \multirow{3}{*}{$\begin{array}{r}\text { Natural } \\
\text { fisheries }\end{array}$} & \multirow{3}{*}{$\begin{array}{l}\text { Egyptian } \\
\text { fisheries }\end{array}$} \\
\hline & \multicolumn{2}{|c|}{ Mediterranean Sea } & \multicolumn{2}{|c|}{ Red Sea } & \multicolumn{2}{|c|}{ The total } & & \\
\hline & $\mathbf{A}$ & $\mathbf{E}$ & $\mathbf{A}$ & $\mathbf{E}$ & $\mathbf{A}$ & $\mathbf{E}$ & & \\
\hline Area $\left(\right.$ acre $\left.^{* 10^{6}}\right)$ & 6.8 & 3.3 & 4.4 & 0.9 & 11.2 & 4.2 & 13.2 & 13.9 \\
\hline $\begin{array}{c}\text { Egyptian marine } \\
\text { fisheries area } \\
(\%)\end{array}$ & 60.7 & 78.6 & 39.3 & 21.4 & 100.0 & 100.0 & - & $\longrightarrow$ \\
\hline $\begin{array}{c}\text { Natural fisheries } \\
\text { area }(\%)\end{array}$ & 51.5 & 25.0 & 33.3 & 6.8 & 84.8 & 31.8 & 100.0 & $\longrightarrow$ \\
\hline $\begin{array}{c}\text { Egyptian } \\
\text { fisheries area } \\
(\%)\end{array}$ & 48.9 & 23.7 & 31.6 & 6.5 & 80.5 & 30.2 & & 100.0 \\
\hline $\begin{array}{c}\text { Coast length } \\
(\mathrm{Km})\end{array}$ & \multicolumn{2}{|c|}{1100} & \multicolumn{2}{|c|}{1300} & \multicolumn{2}{|c|}{2400} & & $\longrightarrow$ \\
\hline $\begin{array}{l}\text { Egyptian marine } \\
\text { fisheries coast } \\
\text { length } \\
(\%)\end{array}$ & \multicolumn{2}{|c|}{46} & & & \multicolumn{2}{|c|}{100.0} & & - \\
\hline
\end{tabular}

A: Actual area for fishing

E: Exploitable area for catching.

Source: Maiyza, 2015 and Google Earth program.

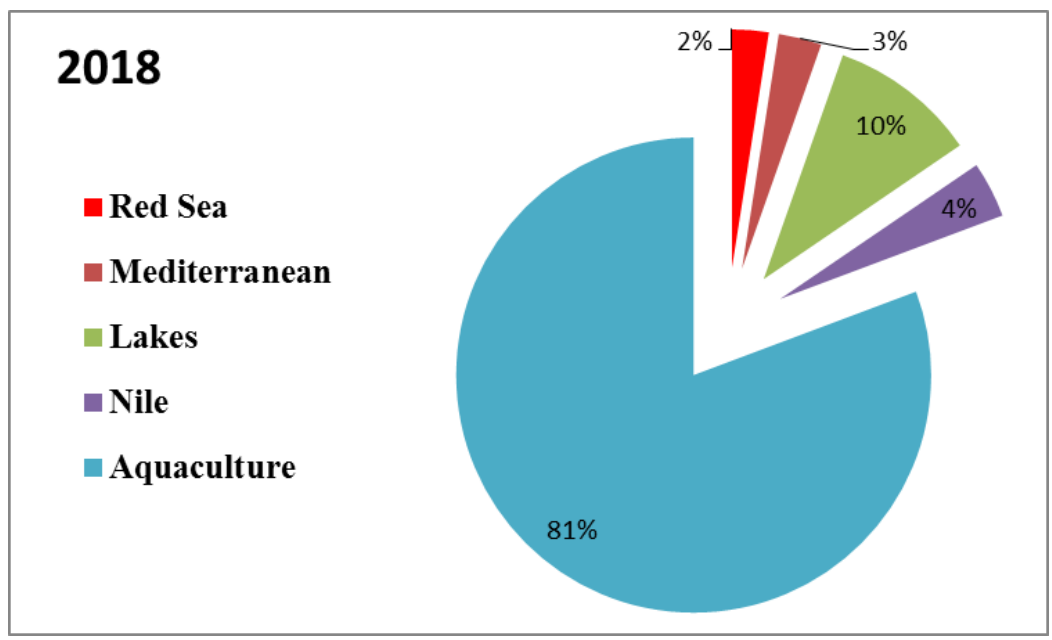

Fig. 2. Contribution of Egyptian marine fisheries in fish production during 2018

From the above illustrated table and graph, Red Sea fisheries is longer in coast length and smaller in its area than in Mediterranean Sea fisheries because of Red Sea coast has many meanders compared to Mediterranean Sea. Consequently, the contribution of Mediterranean fisheries to the fish production in Egypt is more than the contribution of Red Sea fisheries. 
It is worth mentioning that the marine fisheries in Egypt were contributed by $25 \%$ of total fish production in 80's, severly decreased to only 5\% in 2018 (Mehanna, 2020; GAFRD, 2018).

\section{Catch and effort statistics}

The total fish catch in the Egyptian Marine fisheries during the period of the study is about $119.3 * 10^{3}$ tons, which represents about $31.37 \%, 13.3 \%$, from Natural fisheries production, and total Egyptian fish production consequently, (Table 2). The relative importance of the Mediterranean Sea fisheries is higher than The Red Sea fisheries in its contribution to the Egyptian Marine fisheries, natural fisheries and Egyptian fisheries in its fish production and area.

Table 2. Catch in Egyptian marine fisheries during 1995-2016.

\begin{tabular}{ccccc}
\hline $\begin{array}{c}\text { Marine fisheries } \\
\text { (seas) }\end{array}$ & $\begin{array}{c}\text { Average } \\
\text { Production } \\
\text { (tons*10 }^{\mathbf{3}} \text { ) }\end{array}$ & $\begin{array}{c}\text { \% from } \\
\text { Egyptian } \\
\text { Marine } \\
\text { fisheries }\end{array}$ & $\begin{array}{c}\text { \% from } \\
\text { Natural fisheries } \\
\text { production }\end{array}$ & $\begin{array}{c}\text { \% from } \\
\text { total Egyptian fish } \\
\text { production }\end{array}$ \\
\hline Mediterranean Sea & 64.4 & 54.0 & 16.9 & 7.2 \\
\hline Red Sea & 54.9 & 46.0 & 14.4 & 6.1 \\
\hline Egyptian marine fisheries & 119.3 & 100.0 & 31.3 & 13.3 \\
\hline Natural fisheries & 380.2 & - & 100.0 & 42.4 \\
\hline $\begin{array}{c}\text { Total Egyptian fish } \\
\text { production (tons*10 }\end{array}$ & 897.1 & - & - & 100.0 \\
\hline
\end{tabular}

Source: CAPMAS, 2016 and GAFRD, 2016.

There are 10 governorates shared the Egyptian marine fisheries, 7 governorates are lie on Mediterranean Sea and shared its fisheries; arranged according to its productivity as Damietta, Beheira, Port Said, Alexandria, Kafr El-shiekh, North Sinai and Matrouh. Whereas three governorates are shared the Red Sea fisheries, which are Suez, Red Sea and South Sinai (Table 3).

Table 3. Catch and effort of different governorates shared the Egyptian marine fisheries during 1995 - 2016.

\begin{tabular}{|c|c|c|c|c|c|c|c|}
\hline \multirow{3}{*}{\multicolumn{2}{|c|}{ Egyptian Marine fisheries }} & \multirow{2}{*}{\multicolumn{2}{|c|}{ Production }} & \multicolumn{4}{|c|}{ Effort } \\
\hline & & & & \multirow{2}{*}{$\begin{array}{c}\text { Motor } \\
\text { boat }\end{array}$} & \multirow{2}{*}{$\begin{array}{c}\text { Sailing } \\
\text { boat }\end{array}$} & \multicolumn{2}{|c|}{ Total } \\
\hline & & $\left(\right.$ tons $\left.^{*} 10^{3}\right)$ & $\%$ & & & (boat) & $\%$ \\
\hline \multirow{9}{*}{ 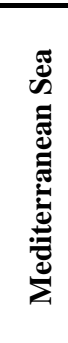 } & Damietta & 19.5 & 30.0 & 830 & 242 & 1072 & 22.9 \\
\hline & Beheira & 13.0 & 19.8 & 617 & 293 & 910 & 19.5 \\
\hline & Port Said & 12.2 & 18.6 & 408 & 494 & 902 & 19.3 \\
\hline & Alexandria & 11.6 & 17.7 & 702 & 395 & 1097 & 23.4 \\
\hline & Kafr El-shiekh & 5.8 & 8.9 & 199 & 216 & 415 & 8.9 \\
\hline & North Sinai & 2.9 & 4.4 & 175 & 54 & 229 & 4.9 \\
\hline & Matrouh & 0.4 & 0.6 & 10 & 41 & 51 & 1.1 \\
\hline & Total & 65.4 & 100.0 & 2941 & 1735 & 4676 & 100.0 \\
\hline & $\%$ of Totals & \multicolumn{2}{|c|}{$53.8 \%$} & $70.5 \%$ & $66.7 \%$ & \multicolumn{2}{|c|}{$69.0 \%$} \\
\hline \multirow{6}{*}{ 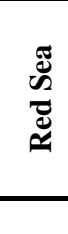 } & Suez & 29.1 & 51.8 & 550 & 341 & 891 & 42.5 \\
\hline & Red Sea & 26.1 & 46.4 & 602 & 456 & 1058 & 50.5 \\
\hline & South Sinai & 1.0 & 1.8 & 79 & 68 & 147 & 7.0 \\
\hline & total & 56.2 & 100.0 & 1231 & 865 & 2096 & 100.0 \\
\hline & $\%$ of Totals & \multicolumn{2}{|c|}{$46.2 \%$} & $29.5 \%$ & $33.3 \%$ & \multicolumn{2}{|c|}{$31.0 \%$} \\
\hline & Totals & \multicolumn{2}{|c|}{121.6} & 4172 & 2600 & \multicolumn{2}{|c|}{6772} \\
\hline
\end{tabular}

Source: CAPMAS, 2016 and GAFRD, 2016. 
Fish catch of Egyptian marine fisheries during 1995-2016 is about $119.3 * 10^{3}$ tons with percentage contribution of 54\% for Mediterranean fisheries and $46 \%$ from Egyptian marine fisheries. Generally there is a decreasing trend in the catch of marine fisheries during the period of study reflecting the decreasing of productivity and relative abundance of these fisheries (Fig. 3).

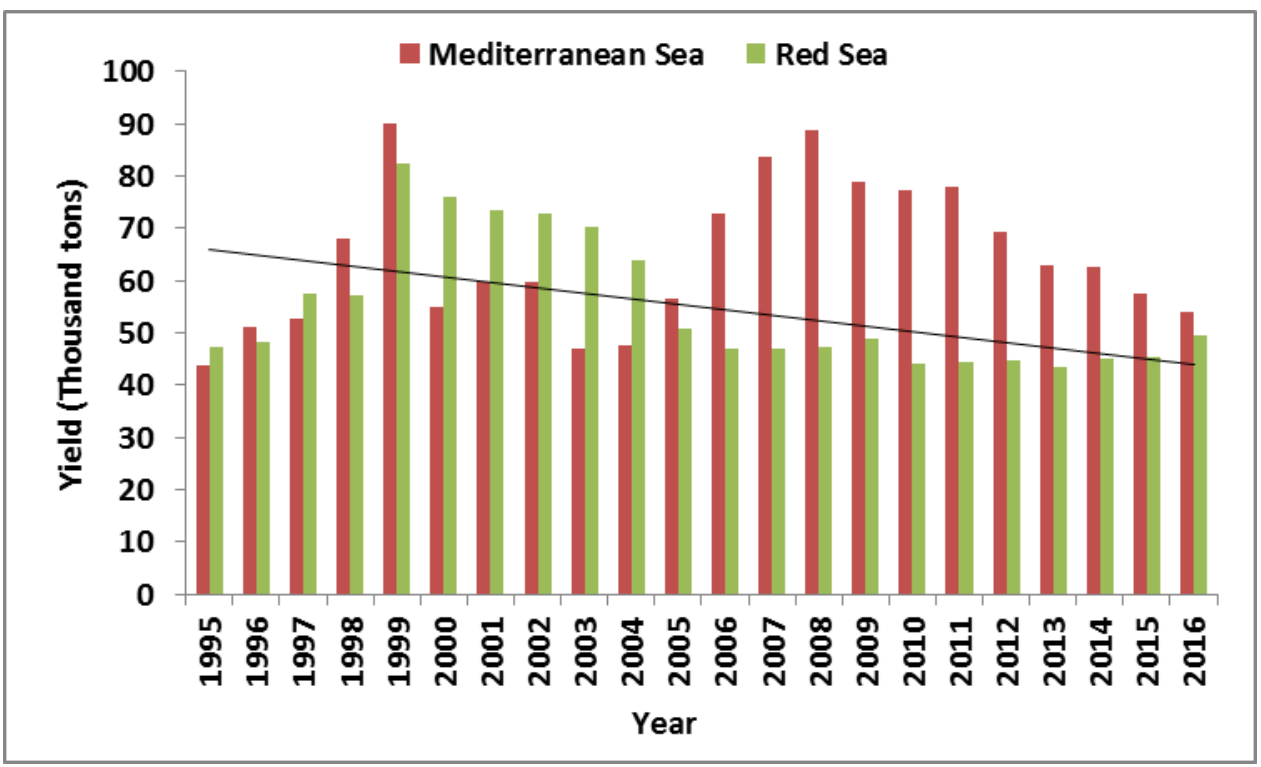

Fig. 3. Trend of fish production from Egyptian marine fisheries during 1995-2016

The fishing effort in Mediterranean and Red Sea fisheries represented by fishing boats are contributed about $69 \%$ and $31 \%$ of fishing effort in Egyptian marine fisheries respectively, which is estimated at about $6.8 * 10^{3}$ boats during the period of the study.

It is noted that the fishing effort represented by the number of fishing vessels in Mediterranean Sea fisheries is higher than Red Sea fisheries; also motor boats are bigger than sailing boats in Egyptian marine fisheries in general (Table 3).

\section{Egyptian marine fisheries management}

Fish stock assessment is very important process because it determines: (1) fisheries productivity, (2) the impact of fishing process on fisheries, (3) the effect of changing fishing rates. So it is essential to ensure the fisheries management and optimum exploitation (Musick \& Bonfil, 2005) by:

- Identify the level of exploitation that gives maximum weighted production in the long term from under study fisheries.

- Fish stocks assessment studies must be direct to fishermen and decision-makers in fisheries management, because these studies answer to number of questions: when and where? What catch? , as well as what is size supposed to catch? and how to fish (fishing methods and tools).

To manage Egyptian marine fisheries and to evaluate its current exploitation situation, the maximum sustainable yield (MSY) and the corresponding level of fishing effort $\left(f_{\max }\right)$ for catch are estimated using the surplus production models. These models deal with the entire stock, the entire fishing effort and the total yield obtained from the 
stock, without details about growth and mortality parameters or the effect of mesh size on the age of fish capture .

To apply Schaefer model on Egyptian marine fisheries, the catch and catch per unit fishing effort expressed as ton/standard fishing unit during 22 years (1995-2016) are used.

\subsection{MSY and $\mathbf{f}_{\max }$ for Mediterranean Sea fisheries}

Schaefer model has been applied on Mediterranean sea fisheries during the period from 1995 to 2016 to estimate the maximum sustainable yield (MSY) and the corresponding level of fishing effort $\left(f_{\max }\right)$ for fish catch (Figs.4 \& 5). The estimated MSY was $73.0^{*} 10^{3}$ ton at fishing effort of $3.5^{*} 10^{3}$ standard boats. These results confirmed the over exploitation situation in the Egyptian Mediterranean fisheries (Table 4) and coincide with the previous studies dealing with the assessing the fish stocks in Mediterranean (eg. Mehanna, 2009, 2014, 2019a\&b; Mehanna and Haggag, 2010\&2011; Mehanna et al., 2011; El-Serafy et al., 2015; Hassanein, 2017).

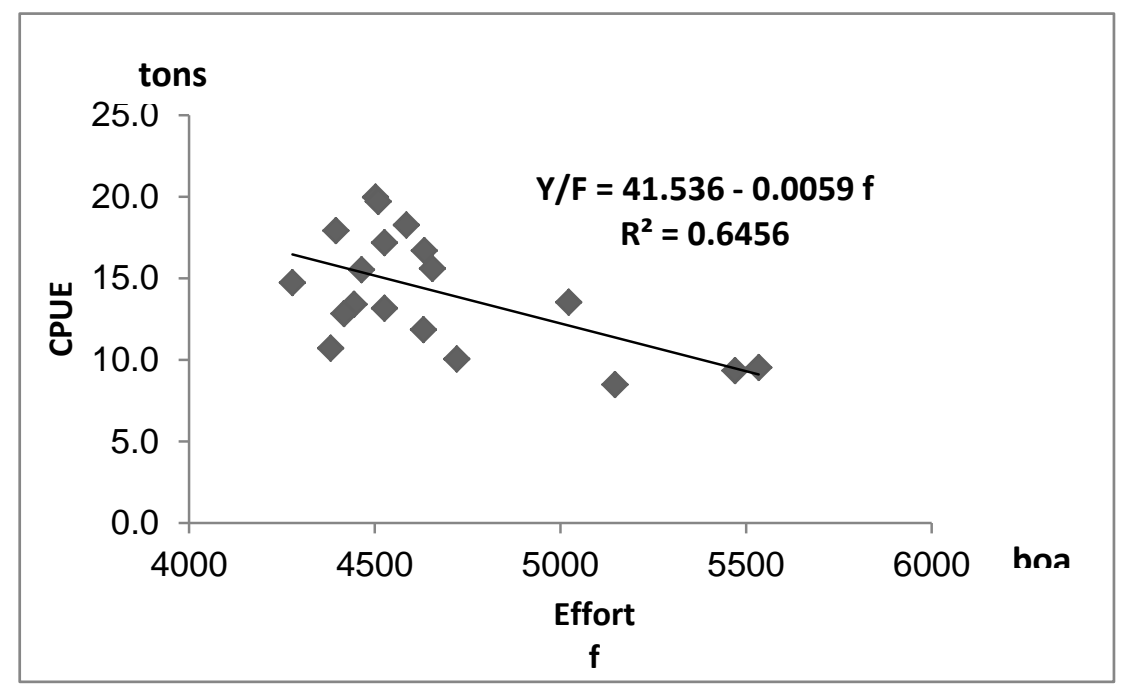

Fig. 4. Relationship between CPUE and effort in Mediterranean Sea fisheries during 1995-2016

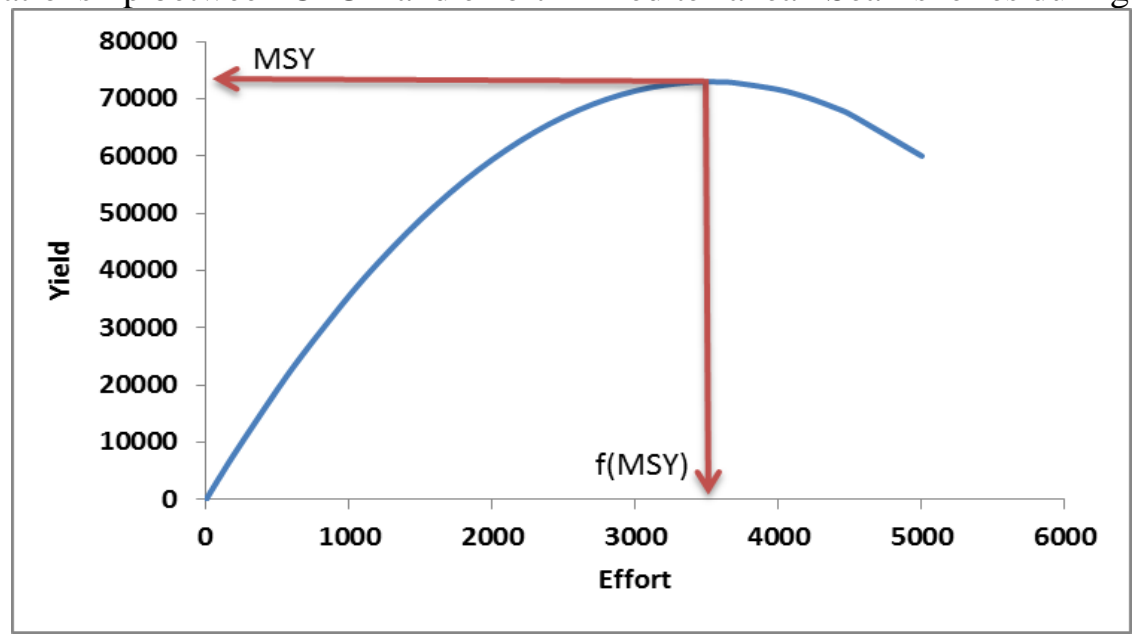

Fig. 5. Yield Curve of Mediterranean Sea fisheries according to Schaefer Model 
Table 4. MSY and $\mathrm{f}_{\max }$ estimated via Schaefer model of Egyptian Marine fisheries during 1995-2016.

\begin{tabular}{|c|c|c|}
\hline $\begin{array}{l}\text { Egyptian marine } \\
\text { fisheries }\end{array}$ & Items & Results \\
\hline \multirow{2}{*}{ 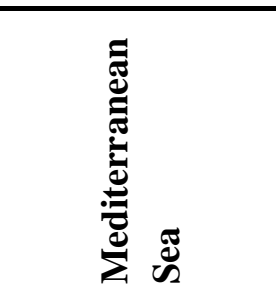 } & \begin{tabular}{ll}
\multicolumn{2}{l}{ Schaefer Model } \\
MSY $^{*}$ & $($ tons \\
$\mathrm{f}_{\max }{ }^{* *}$ & (boats) \\
\end{tabular} & $\begin{array}{c}\mathrm{Y}=41.536 \mathrm{f} \pm 0.0059 \mathrm{f}^{2} \\
73.0 \\
3500\end{array}$ \\
\hline & $\begin{array}{l}\text { Overproduction \%increasing } \\
\text { Effort } \quad \% \text { drcreasing }\end{array}$ & $\begin{array}{l}13.6 \\
25.1\end{array}$ \\
\hline \multirow[b]{2}{*}{ 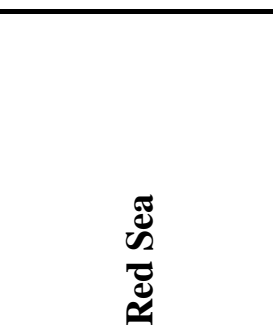 } & $\begin{array}{lc}\text { Schaefer Model } & \\
\text { MSY }^{*} & \text { (tons*10 } \\
\mathrm{F}_{\max }{ }^{* *} & \text { (boats) } \\
\end{array}$ & $\begin{array}{c}\mathrm{Y}=76.21 \pm 0.0234 \mathrm{f}^{2} \\
63.1 \\
1628\end{array}$ \\
\hline & $\begin{array}{l}\text { Overproduction \%increasing } \\
\text { Effort \%drcreasing }\end{array}$ & $\begin{array}{l}14.9 \\
22.3\end{array}$ \\
\hline
\end{tabular}

\subsection{MSY and $f_{\max }$ for Red Sea fisheries}

Schaefer model has been applied on Red Sea fisheries also to estimate the maximum sustainable yield (MSY) and the corresponding level of fishing effort $\left(f_{\max }\right)$ (Figs. $6 \& 7$ ). It is obvious that the value of MSY is $63.1 * 10^{3}$ ton, whereas the value of $f_{\max }$ is $1.6^{*} 10^{3}$ boats. The overfishing situation was observed (Table 4 ) and agreed with all previous studies dealing with tstock assessment of Red Sea fisheries (eg. Mehanna and El-Gammal, 2007; Mehanna, 2005 to 2020; Tesfamichael and Mehanna, 2012; Osman, 2015; Mohamed, 2016; El-Mahdy, 2017; Mehanna et al., 2016, 2017, 2018, 2019; Mohamed et al., 2020).

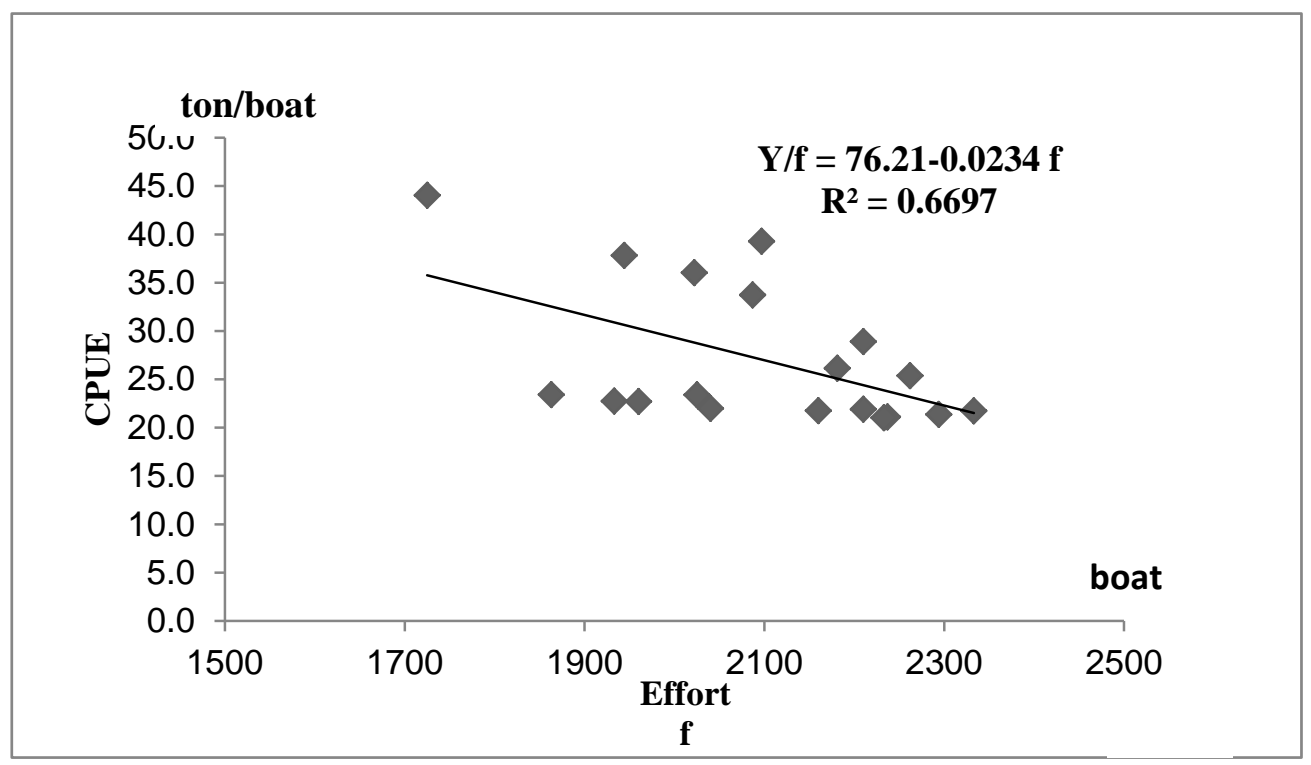

Fig. 6. Relationship between CPUE and effort in Red sea fisheries during 1995-2016. 


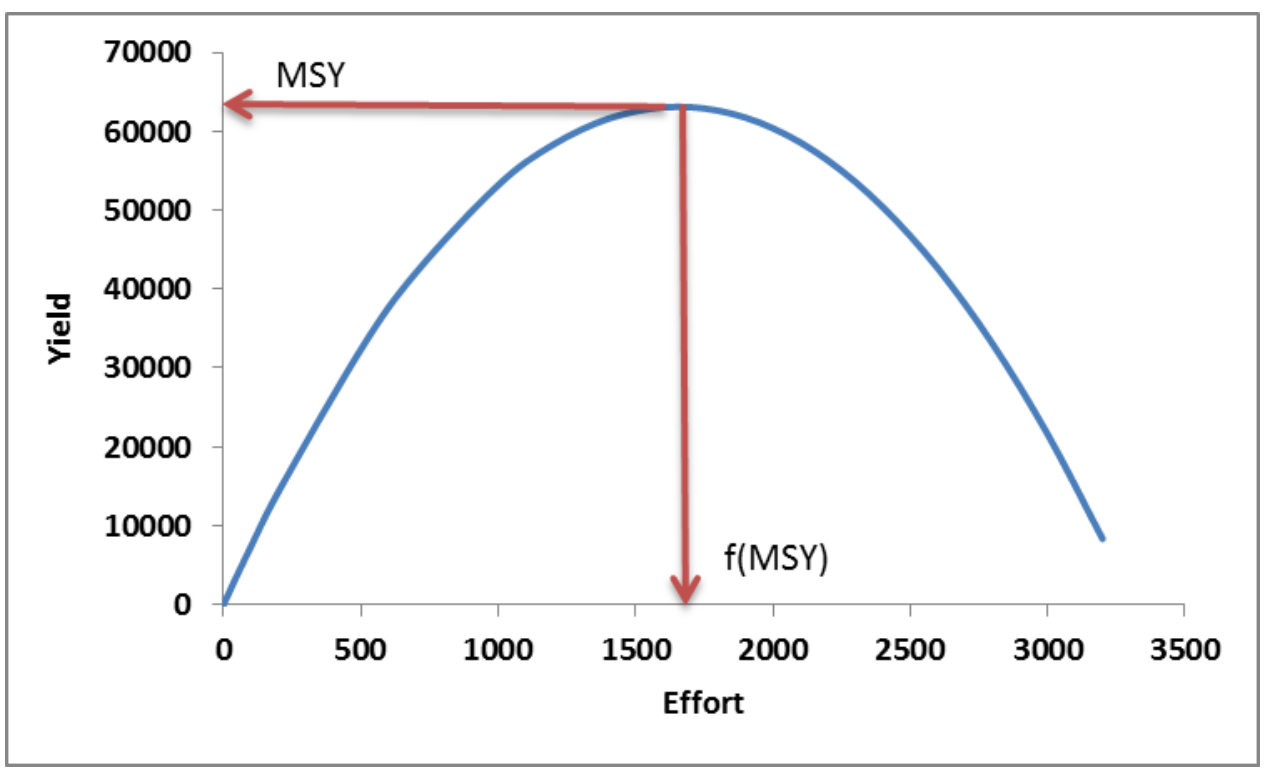

Fig. 7. Yield Curve of Red sea fisheries according to Schaefer Model

In spite of the large area of marine fisheries in Egypt, these fisheries are not exploited rationally due to the decrease of relative abundance of its fish stocks as a result of different reasons such as pollution (domestic and industrial sewages), over fishing and illegal fishing, habitat degradation, human activities on coastal areas, in addition to climate changes. These challenges especially the increasing of fishing effort had affected the sustainability of fish production from Egyptian marine fisheries (Mediterranean Sea $\&$ Red Sea fisheries). This situation was proved by applying Schaefer model (1954) where the estimated optimum effort was less than the actual one in both seas.

The results (Figs. $5 \&$ 7; Table 4) showed that a maximum sustainable yield of about 73.0 and 63.1 thousand ton could be obtained from Mediterranean and Red seas fisheries, respectively. The estimated optimum fishing effort was 3500 and 1656 standard fishing unit for Mediterranean and Red seas fisheries, respectively. This means that, the present level of fishing effort of the two seas fisheries should be decreased to obtain MSY, while for the catch it will be increased by about $13.6 \%$ and $14.9 \%$ of its current value by applying the optimum number of vessels.

\section{CONCLUSION}

In conclusion, based on the obtained results, the Egyptian marine fisheries are in situation of over fishing. Although, there are some regulatory measures to manage these fisheries like closed season for three months in Red Sea and 45 days in Mediterranean, prohibition any new fishing licenses and any improvements on the fishing boats but these regulations not enforced and not sufficient to conserve our fisheries. So, further studies based on the analytical models to assess and manage the different fish stocks exploited by different fishing gears are required. Also, make a data base about the Egyptian fisheries containing good records for fishery statistics to facilitate the evaluation and managing 
these resources is urgent need. As well as, a multi fleet-multi species assessment models should be used in the case of our marine fisheries.

\section{REFERENCES}

Ali, A.G. (2017). An Analytical Economic Study of The Egyptian Red-Sea Fisheries, Ph.D., Faculty of Agriculture, Alexandria University, Egypt, .

CAPMAS (2016). The Central Agency for Public Mobilization and Statistics: Year-book of fishery statistics (1995-1999), Cairo, Egypt.

El-Karashili, A. F. (2010). Production Planning and Management - Marine Industries, Books Sector, Ministry of Education, Rosalieouf Press, Cairo, Egypt

El-Kholei, A. (2008), Is there overexploitation in sardine, mullet and sole catch in the Egyptian Mediterranean Sea fisheries? A supply production model approach, Alexandria Journal Agriculture Research, 53 (2): 1-10.

El-Serafy, S. S.; El-Gammal, F. I.; Mehanna, S. F.; Abdel-Hamid, N. H. and Farrag, E.F.E. (2015). Age, Growth and Reproduction of the Tub Gurnard, Chelidonichthys lucerna (Linnaeus, 1758) from the Egyptian Mediterranean waters off, Alexandria. International Journal of Fisheries and Aquatic Sciences 4(1): 13-20.

El-Mahdy, S. M. (2017). Biological studies, population dynamics and stock assessment of Acanthopagrus bifasciatus from the Red sea, Egypt. PhD Thesis, Assiut Univ.

GAFRD (1995-2018). The Genreal Authority for Fish Resources Development: Yearbook of fishery statistics (1995-2018), Cairo, Egypt.

Gulland, J. A. (1983). Fish stock assessment: a manual of basic methods. Chichester, UK,Wiley Inter science,FAO/Wiley series onfood and agriculture, pp 1-223.

Haddon, M. (2011). Modeling and quantitative methods in fisheries. Second edition, Chapman \& Hall/CRC press, London 449pp.

Hassanein, E. M. (2017). Biological studies, stock assessment and fisheries management of some species of family Mullidae from the Mediterranean Sea at Alexandria. PhD Thesis, Fac. Sci. Assiut University.

Maiyza, SH. I. (2015). An Economic study of Fish Production In Alexandria, Mediterranean Sea Fisheries, Ph.D., Faculty of Agriculture, Alexandria University, Egypt, pp.164-167.

Mehanna, S. F. (2005). Population dynamics of the areolate grouper Epinephelus areolatus from the Egyptian sector of Red Sea. 12th International Conference of Union of Arab Biologists, El-Hodeida University, Yemen.

Mehanna, S. F. (2009). Growth, Mortality and Spawning Stock Biomass of striped red mullet Mullus surmuletus, in the Egyptian Mediterranean waters. Med. Mar. Sci., 10 (2): 5-17.

Mehanna, S. F. (2011). Population dynamics and management of snubnose emperor Lethrinus bungus (L. borbonicus) from the Foul Bay, Red Sea. INOC-XI International Symposium 2011, Bogor, Indonesia: pp.121-129.

Mehanna, S. F. (2014). Population dynamical parameters of the Atlantic lizardfish (Synodus saurus) from the Mediterranean waters of Egypt. International Congress "Estuaries \& Coastal Protected Areas, ECPA; 2014 4-6 November 2014, Turkey. 
Mehanna, S. F. (2019a). An overview on fish production in Egypt and how to achieve its sustainability. $3^{\text {rd }}$ International Conference for Women in Science, 12-14 March 2019.

Mehanna, S. F. (2019b). Stock assessment of European hake, Murleccius murleccius from the Egyptian waters of Mediterranean Sea. Expert group meeting on Hake, Rome, 2-7 December 2019.

Mehanna, S. F. (2020). Challenges faced the small scale fisheries and its sustainable development. ICAR- Central Marine Fisheries Research Institute, Research Centre Mangalore, 7-10 January 2020

Mehanna, S. F. and El-Gammal, F. I. (2007). Gulf of Suez fisheries: current status, assessment and management. J. King Abdulaziz University, Mar. Sci.,18: 3-18.

Mehanna, S. F. and Haggag, H. M. (2010). Port Said Fisheries: current status, assessment and management. 3rd International conference on Fisheries and Aquaculture, 29 November-1December, Cairo, Egypt. www.cabdirect.com.

Mehanna, S. F. and Haggag, H. M. (2011). Maximum sustainable yield of the flatfishes (Family: Soleidae) from Port Said waters, Mediterranean sea, Egypt. Egypt. J. Aquat. Biol. \& Fish., Vol. 15, No. 3:285- 293.

Mehanna S. F.; Fattouh, S. A.; Farrag, E. F. and El-Sherbeny, A. S. (2011). Spatiotemporal variations in the distribution and abundance of demersal fishes in the Egyptian Mediterranean waters. 4th International conference on Fisheries and Aquaculture, 3-5 October, Cairo, Egypt.

Mehanna, S.F.; Mahmoud, U. and Mohammed, A. S. (2016). Fishery status of Carangoides bajad and Caranx melampygus (Family Carangidae) from Shalateen Fishing Area, Red Sea, Egypt, based on yield per recruit (Y/R) analysis. Egypt. J. Aquat. Biol. \& Fish., 20 (2): 61 - 68.

Mehanna, S. F.; Osman, A. M.; Farrag, M. M. and Osman, Y. A. (2017). Age and growth of three common species of goatfish exploited by artisanal fishery in Hurghada fishing area, Egypt. Journal of Applied Ichthyology, 1-5.

Mehanna, S. F.; Mohammed, A. S.; Mohsen, S. and Abdel-Maksoud, Y. (2018). Stock assessment and management of rabbitfish Siganus rivulatus from the Southern Red Sea, Egypt.2nd International conference, Faculty of Science, Ain Shams University "Sustainable Innovations and Sustainable Development SISD, 23-26 October, 2018.

Mehanna, S. F.; Osman, Y. A.; Khalil, M. T. and Hassan, A. (2019). Age and growth, mortality and exploitation ratio of Epinephelus summana (Forsskål, 1775) and Cephalopholis argus (Schneider, 1801) from the Egyptian Red Sea coast, Hurghada fishing area. Egyptian Journal of Aquatic Biology \& Fisheries, 23(4): 65-75. 115.

Mohammad, A. S. (2016). Biological studies, stock assessment and fisheries management of Carangoides bajad (Forsskal, 1775) and Caranx melampygus (Cuvier, 1833) from the Red Sea, Egypt. PhD Thesis, Fac. Sci., Assiut University.

Mohamed, A. S.; Mehanna, S. F.; Osman, Y. A. and El-Mahdy, S. M. (2020). Age, growth and population parameters of the spiny squirrelfish, Sargocentron spiniferum (Forsskål, 1775) from Shalateen fishing area, Red Sea, Egypt. Egyptian Journal of Aquatic Biology \& Fisheries, 24 (2): 469 - 480. 
Musick, J.A. and Bonfil, R. (2005). Management Techniques for Elasmobranch Fisheries. Food and Agriculture Organization of United Nations, FAO Fisheries Technical Paper, No. 474, Rome, FAO, 251 pp.

Osman, Y. A. (2015). Population Dynamics and Stock Assessment of the most important species of Family Scaridae (parrot) in Hurghada, Red Sea. MSc. Thesis, Fishery and Aquaculture Technology, Faculty of Science, Port Said University.

Schaefer, M. B. (1954). Some Aspects of the Dynamic Of Population Important To The Management Of The Commercial Marine Fisheries, Bulletin of the Inter-American Tropical Tuna Commission, 1(2): 27-56.

Tesfamichael, D. and Mehanna, S. F. (2012). Red Sea fisheries of Egypt: Heavy investment and their consequences. In: Tesfamichael, D. and Pauly, D. (eds.) Catch reconstruction for the Red Sea large marine ecosystem by countries $(950-2010)$. Fisheries Centre Research Reports, 20 (1), Vancouver. 